\title{
Rain, Runoff, and Diatoms: the Effects of the North Pacific 2014-2015 Warm Anomaly on Particle Flux in a Canadian West Coast Fjord
}

\author{
Sophia C. Johannessen ${ }^{1}$ (I) $\cdot$ Robie W. Macdonald ${ }^{1} \cdot$ Cynthia A. Wright $^{1}$
}

Received: 15 March 2018 / Revised: 10 December 2018 / Accepted: 11 December 2018 / Published online: 11 March 2019

(C) The Author(s) 2019

\begin{abstract}
Sediment traps were deployed at $50 \mathrm{~m}$ depth in Douglas Channel, a fjord on the west coast of Canada, for 3 years (July 2013-July 2016). Particle flux was related to rain, freshwater discharge, and phytoplankton blooms. The North Pacific warm water anomaly (known popularly as the Blob) reached coastal waters during the second year of deployment, resulting in more autumn rain and less snow than during the other 2 years. The maximum particle flux was associated with the snowfed river freshet in May during the first year and with heavy October rains during the second and third years. A protracted sedimentation event consisting of copious diatoms occurred during the warm, second winter (December 2014-February 2015). Silica (empty diatom frustules) was exported, intercepting silicate from local rivers that might otherwise have reached the outer shelf. The effects of extreme climate events are experienced differently inshore than offshore, because they are mediated by local hydrology. During the Blob year, Douglas Channel experienced exceptionally high rainfall in October, which resulted in high particle flux. As the climate continues to warm, mild, rainy years like 2014-2015 will become more common, with the possibility of further winter blooms.
\end{abstract}

Keywords Sediment trap · Sinking particles · Climate change · Coastal waters · "The Blob" warm anomaly · Winter phytoplankton bloom

\section{Introduction}

Sinking particles carry organic and inorganic matter from the surface into the interior of the ocean. They supply food for zooplankton (Dagg 1993), transport contaminants (Olsen et al. 1982), and carry organic carbon into the deep water or sediments, where it can be sequestered away from the atmosphere (Smetacek 1985).

In the open ocean, sinking particle flux is dominated by phytoplankton (Fischer and Karakas 2009; Gardner et al. 1993; Peña et al. 1996, 1999), including rapidly sinking masses of diatoms (Smetacek 1985). In coastal and inshore

Communicated by Hans W. Paerl

Electronic supplementary material The online version of this article (https://doi.org/10.1007/s12237-018-00510-0) contains supplementary material, which is available to authorized users.

Sophia C. Johannessen

Sophia.johannessen@dfo-mpo.gc.ca

1 Fisheries and Oceans Canada, Institute of Ocean Sciences, $9860 \mathrm{~W}$. Saanich Rd., P.O. Box 6000, Sidney, BC V8L 4B2, Canada waters, the sinking flux is much higher, as the phytoplankton and other marine-derived particles mix with terrigenous particles from rivers and distributed land runoff (Baker 1984; Thunell 1998; Timothy et al. 2003). The flux and composition of sinking particles in coastal waters varies on daily to interannual timescales (Timothy et al. 2003), as a result of variations in primary productivity, land runoff, and coastal upwelling (Johannessen et al. 2005; Zúñiga et al. 2016). The strong short-term to seasonal variability gives rise to what has been termed underwater weather (Johannessen et al. 2017).

The drivers of particle flux in coastal waters-sediment discharge from rivers, coastal erosion, and primary production - are affected by local hydrological conditions, which reflect trends and variability at global to local scales. Glacial meltwater contributes to the discharge of many coastal rivers that flow into the Douglas Channel system (Morrison et al. 2012; Caamano watershed), including the Kitimat, Kemano, and Kildala rivers (Fig. 1). Coastal carbon cycling in northern fjords is sensitive to glacial retreat, because glacial runoff may supply significant quantities of petrogenic organic matter (Cui et al. 2016), some of which is labile (Hood et al. 2009). In addition to long-term secular changes, short-term 
Fig. 1 Map of the study area. The black dot marks the mooring site (FOC1)

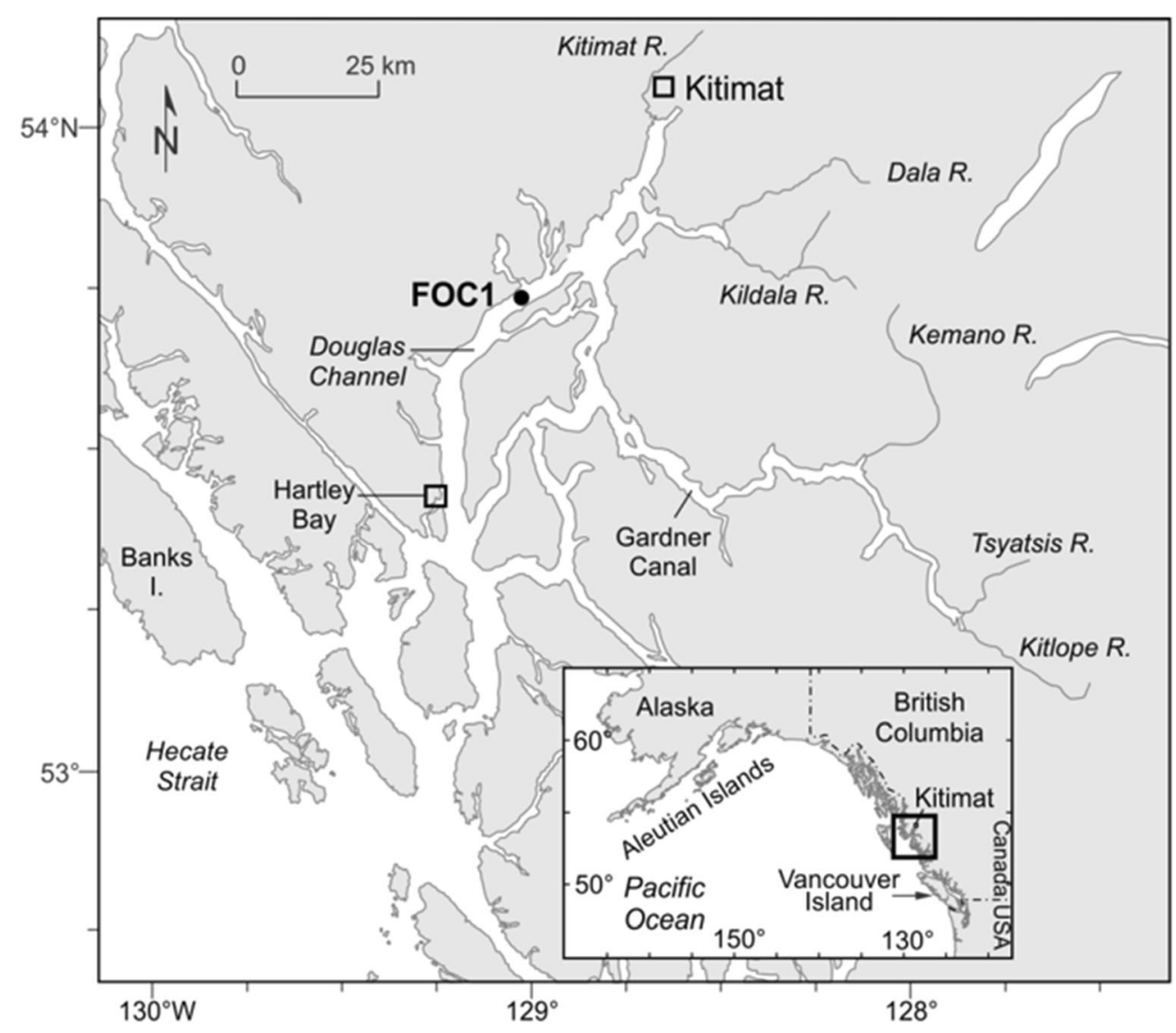

climate variability, which is increasing as the climate warms (Stocker et al. 2013), also affects particle flux (e.g., Johannessen et al. 2017). Most particles discharged by small rivers enter the ocean during and immediately after storms (Kniskern et al. 2011).

An unusual, recent climate event in the North Pacific Ocean was the development of a large patch of exceptionally warm water in the spring of 2014. The patch persisted through 2015 as a result of reduced winter cooling (Bond et al. 2015). "The Blob," as this patch became popularly known, affected coastal weather and was associated with changes in the composition of marine biota in the open ocean. The warm surface water appears to have favored warm water zooplankton species, including an enormous bloom of the gelatinous hydrozoan Velella velella, and sharks and squid were observed far north of their usual range (Bond et al. 2015).

For temperate and northern coasts of western Canada, a warmer climate results in a higher ratio of rainfall to snowfall, as well as a change in the timing of river discharge (Morrison et al. 2002). Since particle flux is strongly affected by changes in local freshwater discharge (e.g., Johannessen et al. 2017), we might expect to see a change in particle flux, composition, or timing, as a consequence of the exceptionally warm conditions offshore.
Here, we present a 3-year sediment trap record (July 2013July 2016) of sinking particle flux and composition at a site in Douglas Channel, spanning the time period of the warm water anomaly. We discuss the main drivers of variability in particle flux during this time and comment on the implications for future trends in the timing, magnitude, and composition of particle flux and on the possibility of winter phytoplankton blooms in coastal British Columbia.

\section{Study Area}

Douglas Channel is the major passage of a complex fjord system on the north coast of British Columbia (Fig. 1). The fjord system was carved by glaciation and is strongly marked by glacial features (Shaw et al. 2017). The average annual rainfall is $2.5 \mathrm{~m}$ at Kitimat and $4.5 \mathrm{~m}$ at Hartley Bay. The average freshwater discharge into the system (from rivers + distributed runoff) is $1200-1300 \mathrm{~m}^{3} \mathrm{~s}^{-1}$, about $40 \%$ of which flows directly into Douglas Channel (Wan et al. 2017).

The whole fjord system acts as an estuary (Macdonald et al. 1983a), with sources of freshwater and particles at the head of Douglas Channel (Kitimat and Kildala rivers), in Gardner Canal (Kemano, Kitlope, and Tsayatis rivers), and along the sides of the channels in numerous streams and waterfalls. Wan et al. (2017) described a four- to five-layer circulation at the 
study site in Douglas Channel (FOC1, Fig. 1): (1) a thin, landwards, wind-driven surface layer $(0-3 \mathrm{~m})$ in summer only; (2) an estuarine outflow (4-32 m); (3) a return inflow (33-131 m); (4) a second outflow above sill depth (83-149 m); and (5) a deep inflow, which renews the deep water in May-June each year.

Macdonald (1983) described the dynamics of suspended and sinking particles measured during October 1978 and February 1979. They identified the main sources of particles as runoff from the rivers and from small streams and observed that the concentration of suspended particles in surface water was significantly higher in October (the rainy season) than in February (winter). They observed that coarse particles $(\geq$ $125 \mu \mathrm{m}$ diameter) fell out of suspension within minutes. Fines flocculated and sank until the concentration of suspended particles decreased to about $10 \mathrm{ppm}$, after which fines continued to be removed from the system for about 5 days. A time series at a single location does not represent the spatial variability throughout the whole fjord system, but it illustrates temporal dynamics in a way that is impossible by other means.

\section{Methods}

\section{Mooring}

A mooring was deployed in Douglas Channel, British Columbia (FOC1, $367 \mathrm{~m}$ bottom depth), from July 2013 to June 2016 (Fig. 1; Table 1). Throughout this paper, year 1 refers to July 2013-June 2014, year 2 to July 2014-June 2015, and year 3 to July 2015-June 2016. Successive deployments were located within $1 \mathrm{~km}$ of each other. The mooring included three Baker-style sequential sediment traps (Baker and Milburn 1983; O'Brien et al. 2000) at $50 \mathrm{~m}$ depth, as well as an array of electronic instruments (Fig. 2). A SeaBird SBE19p conductivity-temperature-depth sensor (CTD) and a Wetlabs FLNTU fluorometer-turbidity meter were attached $1.6 \mathrm{~m}$ below the sediment traps. A Nortek Aquadopp current meter was attached $1 \mathrm{~m}$ below the CTD package.

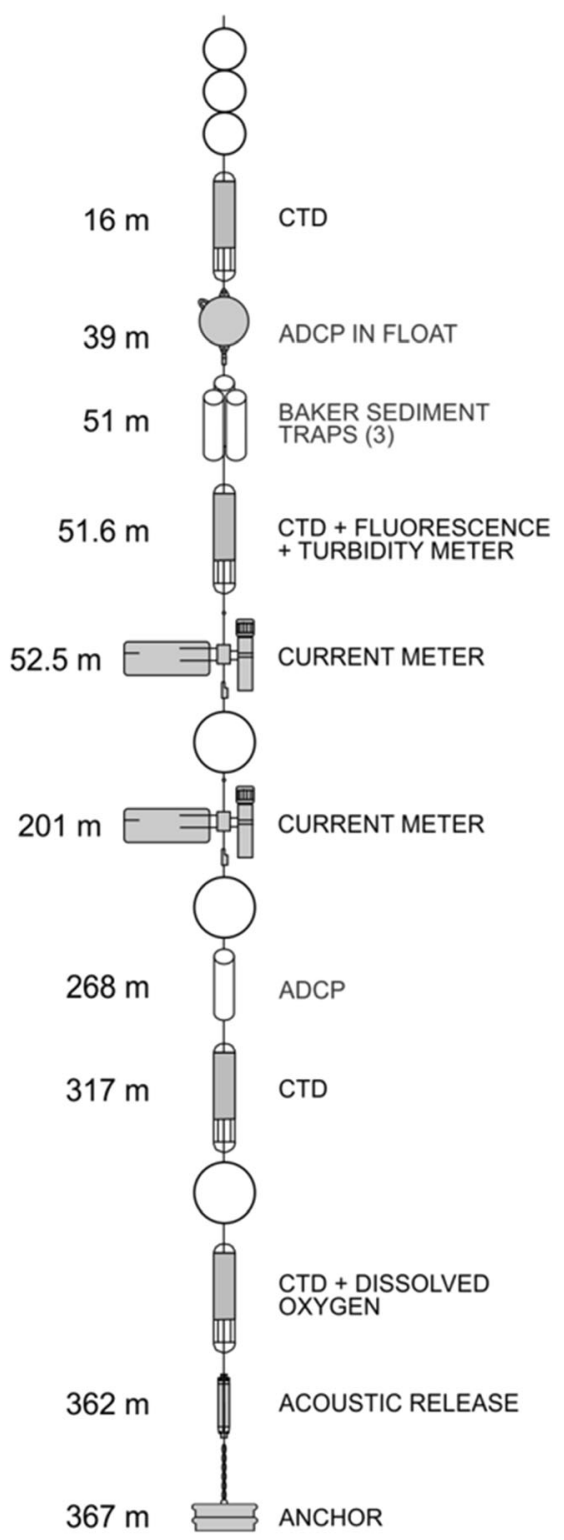

Fig. 2 Mooring instrumentation. Note that the vertical depth is not to scale

Additional instruments were deployed deeper on the mooring, and water samples were collected on all cruises. Data from those sensors and water samples are summarized

Table 1 Deployment details for sediment trap mooring FOC1. Three 10-cup traps were deployed to run consecutively during each deployment, for a total of 30 cups per deployment, except where samples were lost due to trap failure or incomplete preservation of samples

\begin{tabular}{llllll}
\hline Trap deployment & Latitude (N) & Longitude (W) & Dates & $\begin{array}{l}\text { Collection } \\
\text { interval (days) }\end{array}$ & Notes \\
\hline FOC1-A & $53^{\circ} 44.047^{\prime}$ & $129^{\circ} 2.209^{\prime}$ & July 3, 2013-June 13, 2014 & 11.5 & $\begin{array}{r}\text { Trap 2 cups 9-10 lost } \\
\text { (January 26-February 18, 2014) }\end{array}$ \\
FOC1-B & $53^{\circ} 44.13^{\prime}$ & $129^{\circ} 01.72^{\prime}$ & July 2, 2014-June 27, 2015 & 12.0 & Trap 1 cups 1, 5, 7-9 not preserved \\
FOC1-C & $53^{\circ} 44.047^{\prime}$ & $129^{\circ} 02.209^{\prime}$ & Aug 1, 2015-July 11, 2016 & 11.5 & . \\
\hline
\end{tabular}


by Wright et al. $(2015,2016,2017)$ and will not be discussed further here. The data from all the sensors and traps are maintained in the Institute of Ocean Sciences Data Archive (http:// www.pac.dfo-mpo.gc.ca/science/oceans/data-donnees/indexeng.html) and are available upon request.

\section{Sediment Traps}

Each sediment trap contained a carousel of 10 collection cups, with each cup set to collect for 11.5-12 days (Table 1). The three traps were set to operate sequentially, so that as the last cup on one trap finished collecting, the first cup on the next trap began to collect. Together the traps collected a continuous record of sinking particles at each site for nearly a year. Currents at the trap depth were $<20 \mathrm{~cm} / \mathrm{s}$ more than $87 \%$ of the time, which implies that these cylindrical traps did not significantly over- or undercollect sinking particles (e.g., Gardner et al. 1997).

Fine mineral particles could have reached the trap from as far away as Kitimat (Fig. 1; $45 \mathrm{~km}$ landward of FOC). With an average sinking velocity for fine particles of $8 \mathrm{~m}^{\text {day }}{ }^{-1}$, without accounting for flocculation or biological removal processes, Macdonald (1983) calculated that 99\% of the fines would settle out of the top $10 \mathrm{~m}$ within 5 days, so it could take longer than 5 days for the particles to sink to $50 \mathrm{~m}$. (Longchain diatoms and fecal pellets would sink more quickly than this.) The seaward surface velocity is $\leq 0.2 \mathrm{~m} / \mathrm{s}$ (Wan et al. 2017), so Kitimat River outflow could reach mooring site FOC in about 3 days.

During the three deployments, the traps collected particles for 322,360 , and 345 days. Some data were lost due to trap failures (Table 1). The collection cups were filled with a brine and mercuric chloride solution $\left(\mathrm{S}=38-40,\left[\mathrm{HgCl}_{2}\right]=\right.$ $1 \mathrm{mg} \mathrm{mL}^{-1}$ ) before deployment to preserve the samples. During the third deployment, a number of samples in the first trap (cups $1,5,7,8,9$ ) were not properly preserved and so were not included in further analysis.

On recovery, the sediment trap samples were poured through a 500- $\mu \mathrm{m}$ sieve to separate zooplankton "swimmers" from the finer particles. Both portions were retained for further analysis. On return to the laboratory, the $<500-\mu \mathrm{m}$ fraction was split using a McLane wet sample divider into one fourth and three fourth portions. The larger split was sent for analysis of total dry mass and, where sample quantities permitted, geochemical analysis. The smaller split was retained for taxonomic analysis of phytoplankton and enumeration of zooplankton fecal pellets.

\section{Geochemical Analysis of Particles from Sediment Traps}

Sample drying, grinding, weighing, and geochemical analyses were carried out at the University of British Columbia. The samples were rinsed with freshwater before analysis to remove salt. Carbonate carbon was measured by coulometry on acidified samples (Calvert and Pedersen 1995). Total carbon and nitrogen were determined using a Carlo-Erba CHN analyzer, following Calvert and Pedersen (1995), $( \pm 0.3 \%)$, and organic carbon was calculated by the difference between total and inorganic carbon. Silica was analyzed by $\mathrm{Na}_{2} \mathrm{CO}_{3}$ extraction followed by molybdate blue spectrophotometry (Mortlock and Froelich 1989, $\pm 0.6 \%$ ). Stable isotopes of carbon and nitrogen were measured at the Pacific Center for Isotopic and Geochemical Research at the University of British Columbia, by VG PRISM isotope ratio mass spectrometry with a CarloErba CHN analyzer in line (Calvert et al. 2001). $\delta^{13} \mathrm{C}$ and $\delta^{15} \mathrm{~N}$ were reported relative to the Pee Dee Belemnite standard $( \pm 0.2 \% \circ)$ and to air $( \pm 0.3 \% \circ)$, respectively.

\section{Taxonomic Analysis of Phytoplankton and Enumeration of Zooplankton Fecal Pellets}

Phytoplankton were identified and zooplankton fecal pellets enumerated by Dr. Louis Hobson in six of the sediment trap samples (August 25, 2014; November 5, 2014; December 23, 2014; January 16, 2015; February 1, 2015; May 16, 2015). The samples were selected to represent different oceanographic conditions during the second year. Material was examined under a research microscope at $\times 125$ magnification, using an ocular micrometer to define boundaries. Phytoplankton were identified to the lowest taxonomic level (Hobson 2009).

\section{River Discharge and Precipitation Data}

Kitimat River discharge data (Station 08FF001) were provided by Environment and Climate Change Canada, through the Water Office website (https://wateroffice.ec.gc.ca/). Measurements of rain, snow, and total precipitation at Kitimat were provided by Environment and Climate Change Canada, through the Historical Climate Data website (http://climate. weather.gc.ca/). Environment and Climate Change Canada had converted the snow accumulations to water equivalents, using a factor of 10 ( $1 \mathrm{~cm}$ of snow $=1 \mathrm{~mm}$ of water equivalent.)

\section{Statistical Analysis}

Average daily mass fluxes and composition in years 1 and 2 were calculated and then compared to one another using two-sample $t$ tests, assuming unequal variances. Year 3 was excluded from these comparisons, because a number of high-flux samples from July and October 2016 were spoiled. However, year 3 still appears on the plots for the qualitative comparison of seasonal patterns. We also determined mean, standard deviation, and range for the 50 -year rain and river flow records and ranked 2014-2015 within that larger dataset. 


\section{Results}

\section{Total Dry Mass Flux and Composition}

The daily mass flux was highly variable, with $50 \%$ of the total annual flux accumulating in about $25 \%$ of the days in the first 2 years (Table 2). Total dry mass flux into the sediment traps at FOC ranged from 0.077 to $3.0 \mathrm{~g} \mathrm{~m}^{-2}$ day $^{-1}$ (Fig. 3a). In the first year (July 2013-June 2014), the maximum flux occurred in May 2014 (1.2 $\mathrm{g} \mathrm{m}^{-2} \mathrm{day}^{-1},>3$ standard deviations above the average daily rate for year 1 ; Table 2 ), whereas it occurred in October during the second and third years $\left(3.0 \mathrm{~g} \mathrm{~m}^{-2}\right.$ day $^{-1}$ in October 2014, > 3 standard deviations above the average daily rate for year 2 ; Table 2).

The average daily flux for year 2 was about 2.7 times than for year 1 (Table 2). Fall-winter particle flux (OctoberFebruary) was much higher in the second year than the first $(p<0.05)$. Nine of the top 10 depositional events in the 3-year record (as measured at 11.5-12-day resolution) occurred during the second year, between October 2014 and April 2015.

The daily average fluxes of organic carbon and nitrogen were all higher in the second year as well (Table 2). The concentrations of organic $\mathrm{C}$ and $\mathrm{N}$ were lower in the second year because of a higher flux of inorganic particles $(p<0.05$; Table 2).

The sinking particles were predominantly inorganic (Fig. $3 b-d$ ), with organic carbon comprising $4.3-22 \%$ of the material (average $8 \%$ over the whole record, Fig. 3b). Inorganic carbon generally ranged from 0.12 to $0.98 \%$, with a single peak of $1.8 \%$ in mid-September, 2014 (Fig. 3c). The proportion of nitrogen ranged from 0.37 to $2.1 \%$ (average $0.88 \%$, Fig. $3 \mathrm{~d}$ ). Both the $\%$ organic $\mathrm{C}$ and the $\% \mathrm{~N}$ were greater in the first year than the second $(p<0.05$; Table 2$)$. The molar $\mathrm{C} / \mathrm{N}$ ratio was 7.1-21 (data not shown). Biogenic silica ranged from 3.5 to $24 \%$ (Fig. 3e), with a different seasonal pattern from $\mathrm{C}$ and $\mathrm{N}$. (There was insufficient material to measure $\mathrm{Si}$ in most of the year 1 samples.) The proportion of silica tended to shift suddenly between 4-5 and 15-20\% and remain in one or the other of these two modes for weeks to months at a time.
The fluxes of organic carbon and nitrogen were strongly related to one another and to total flux (Fig. 4), although the \% $\mathrm{C}$ and $\% \mathrm{~N}$ were not related to total flux (data not shown). The $\delta^{13} \mathrm{C}$ was positively related to $\% \mathrm{Si}\left(r^{2}=0.7, n=55\right)$ and more weakly negatively related to the $\mathrm{C} / \mathrm{N}$ ratio $\left(r^{2}=0.4, n=85\right.$; data not shown).

\section{Phytoplankton Taxonomy and Zooplankton Fecal Pellet Enumeration}

The complete taxonomic analysis of the six sediment trap samples is presented in the Supplementary Information (Table S1). Of the six samples analyzed (August 25, 2014; November 5, 2014; December 23, 2014; January 16, 2015; February 1, 2015; May 16, 2015), the number of diatoms per sample was lowest in May 2015 and November 2014 (1.0 × $10^{4}$ and $9.8 \times 10^{4}$, respectively). The flux of diatoms was two orders of magnitude higher during the winter bloom sedimentation event $\left(2.3 \times 10^{6}-8.2 \times 10^{6}\right.$ diatoms per sample) (Fig. 5). During the winter bloom, the phytoplankton species assemblage was dominated by the large, chain-forming diatoms Skeletonema marinoi and Thalassiosira nordenskoldii (Table S1). The flux of fecal pellets was also higher during the winter bloom event (Fig. 5).

\section{Temperature, Turbidity, and Chlorophyll}

A temperature sensor moored just below the sediment traps at FOC recorded a strong seasonal pattern (Fig. 6), with high temperatures in the autumn each year (September-November). The peak lasted longer in the second year than the first, and longer again, though at a lower temperature, in the third year. The most striking difference in seasonal pattern among the 3 years was that the temperature did not decrease as much in the winter in the second and third years as it did in the first.

Chlorophyll was variable, with frequent spikes during the 3-year study period (Fig. 7a). The cumulative sum of Chl a increased gradually, in many small increments, over the whole period.
Table 2 Annual total and daily average fluxes for the first two deployment years at station FOC1. The third year is not included, because eight of the samples from autumn, 2015, were unusable but appeared to contain a large proportion of that year's flux. Values in italics indicate significant differences between year 1 and year $2(p<0.05)$. Precision estimates indicate one standard deviation

\begin{tabular}{|c|c|c|}
\hline & $\begin{array}{l}\text { Year } 1 \\
\text { July 2013-June } 2014\end{array}$ & $\begin{array}{l}\text { Year } 2 \\
\text { July 2014-June } 2015\end{array}$ \\
\hline No. of collection intervals $(n)$ & 28 & 30 \\
\hline Average daily flux $\left(\mathrm{g} \mathrm{m}^{-2}\right.$ day $\left.^{-1}\right)$ & $0.30 \pm 0.24$ & $0.80 \pm 0.66$ \\
\hline No. of days and ( $\%$ days) to half total flux & $80(25 \%)$ & $84(23 \%)$ \\
\hline $\begin{array}{l}\text { Average daily organic } \mathrm{C} \text { flux } \\
\left.\left(\mathrm{g} \mathrm{m}^{-2} \text { day }^{-1}\right) \text { and (av. \% organic } \mathrm{C}\right)\end{array}$ & $0.025 \pm 0.017(9.2 \pm 3.3 \%)$ & $0.048 \pm 0.035(7.1 \pm 2.6 \%)$ \\
\hline Average daily $\mathrm{N}$ flux $\left(\mathrm{g} \mathrm{m}^{-2}\right.$ day $\left.^{-1}\right)$ and (av. $\left.\% \mathrm{~N}\right)$ & $0.0030(1.1 \%)$ & $0.0050(0.8 \%)$ \\
\hline Average daily rain (mm/day) & $6.0 \pm 10.8$ & $6.7 \pm 12.6$ \\
\hline Average river discharge $\left(\mathrm{m}^{3} \mathrm{~s}^{-1}\right)$ & $125 \pm 96$ & $147 \pm 120$ \\
\hline
\end{tabular}


Fig. 3 Time series of sinking particle flux and composition captured in the sediment trap at $50 \mathrm{~m}$ depth at station FOC1. Vertical, dashed lines separate calendar years. Deployment years (July-June) are indicated with horizontal bars at the top of panel a, and year 2 data are shown in gray. a Dry mass flux $\left(\mathrm{g} \mathrm{m}^{-2}\right.$ day $^{-1}$ ). b \% organic carbon. $\mathbf{c} \%$ inorganic carbon. $\mathbf{d} \%$ total nitrogen. e Stable isotope ratio, $\delta^{13} \mathrm{C}(\% o$ ) (diamonds), \% biogenic silica (squares)
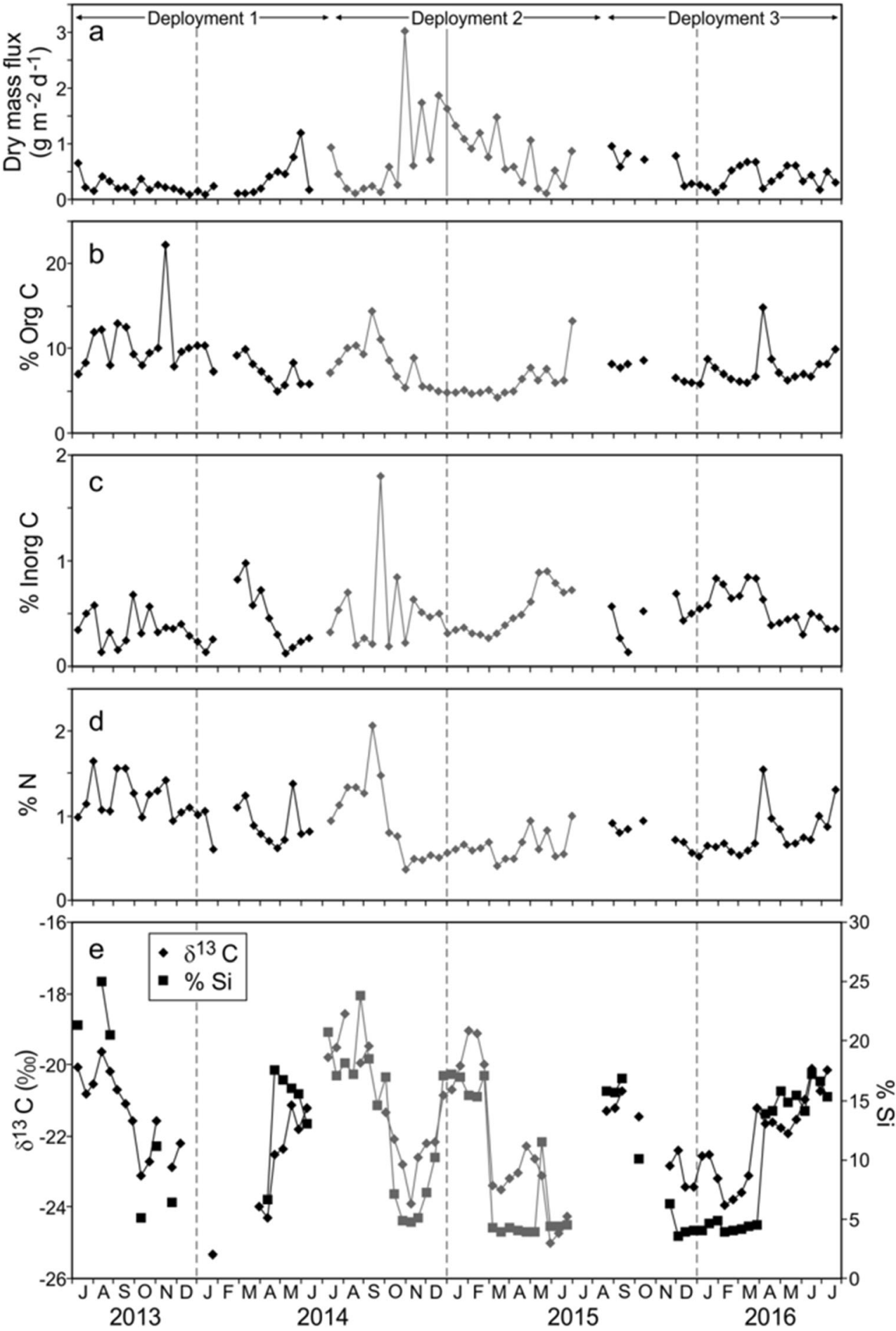

Turbidity in the first year was generally low, with occasional spike. In the second year, turbidity was high and highly variable, especially in late September and throughout October of 2014 (Fig. 7b). The cumulative sum of turbidity shows a slow, steady increase, reflecting a nearly constant low background throughout the first year, followed by a large step change in October of the second year due to a short period of multiple episodes of high turbidity. (There are no turbidity data available for the third year.)

\section{Precipitation and River Flow}

The winter of 2014/2015 also had an exceptionally low snowfall relative to winters preceding and following (compare 
Fig. 4 Compositional relationships for particles captured in the sediment traps: a flux of organic carbon vs. total dry mass flux, $\mathbf{b}$ flux of organic carbon vs. flux of total nitrogen, and $\mathbf{c}$ flux of inorganic carbon vs. total dry mass flux
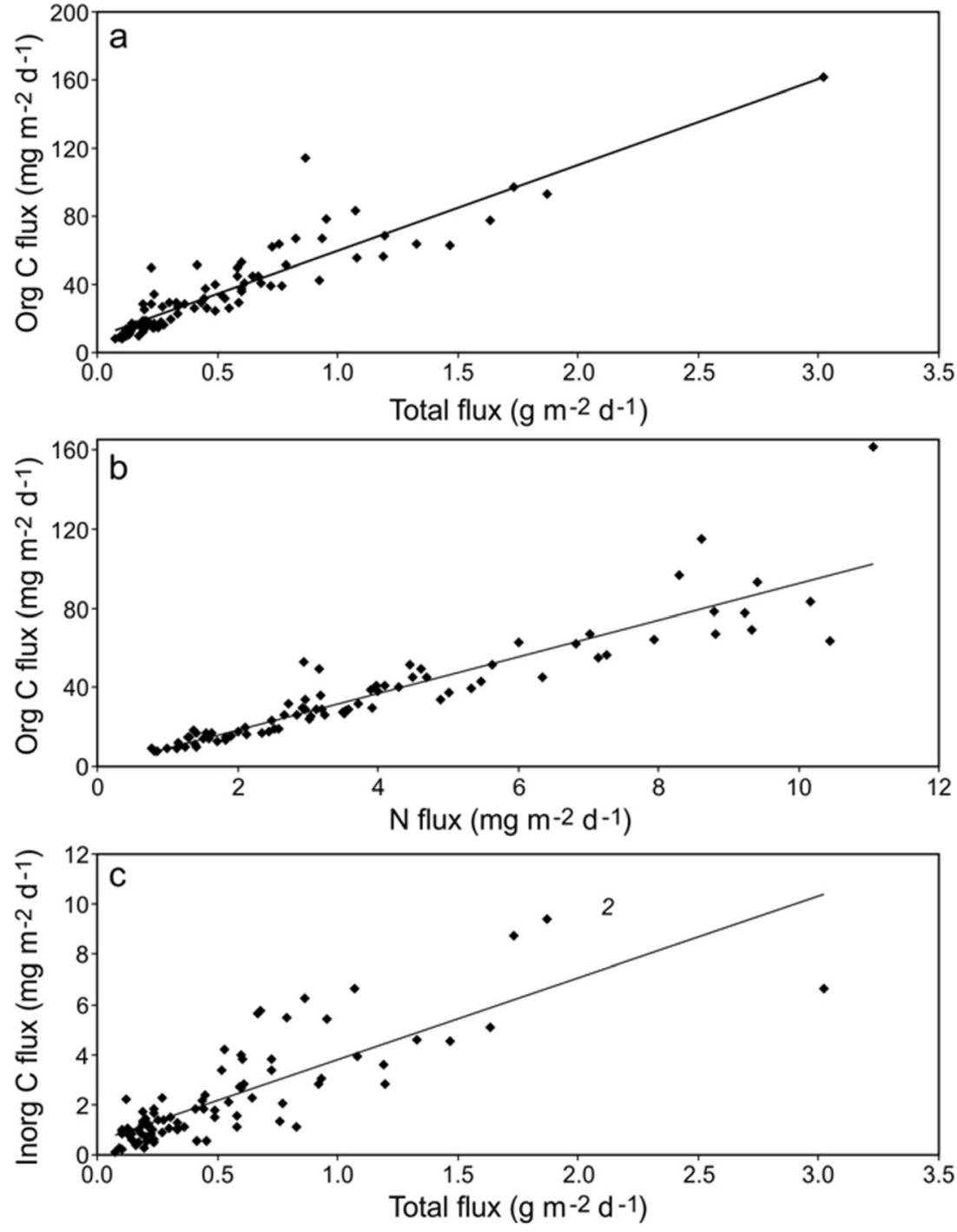

Fig. 8 b to Fig. 8 a, c and to the 50-year mean (Fig. 8d). The total precipitation was highest in year 2 and lowest in year 1 (Table 2), with a much higher proportion of rain to snow in the second and third years than in the first.
The Kitimat River is a mixed snow- and rainfed river, with the basin incorporating glaciated regions up to $1300 \mathrm{~m}$ in elevation. Its annual hydrograph, therefore, reflects relative proportions of rain and snow in the basin. The seasonal
Fig. 5 Number of diatoms and number of fecal pellets per sample counted in six samples from year 2. Full taxonomic data in Table S1

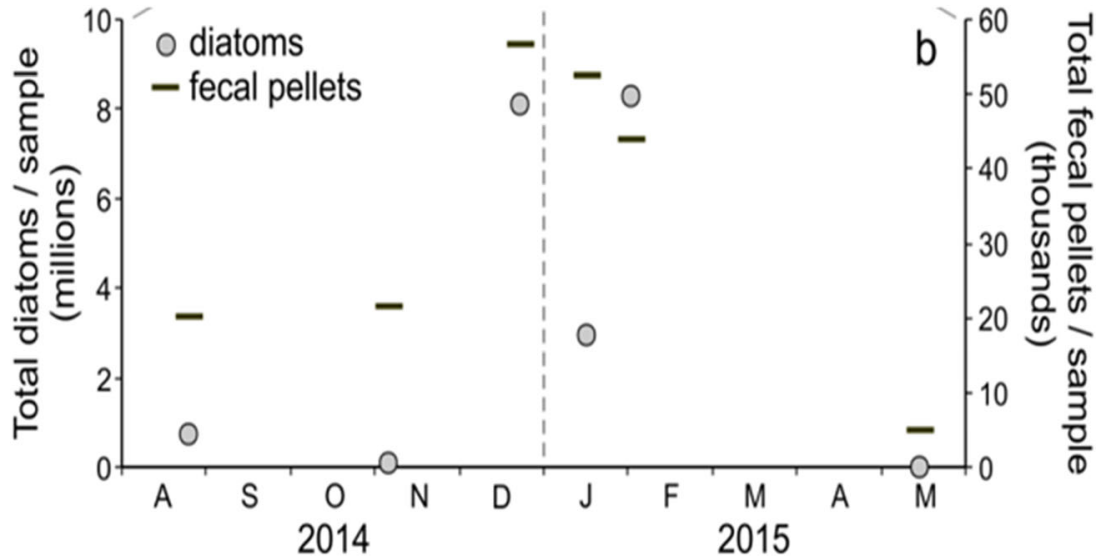


Fig. 6 Time series of temperature measured just below the sediment traps at station FOC1. The dashed, vertical lines separate calendar years; the changes from black to gray and gray to black indicate divisions between deployments

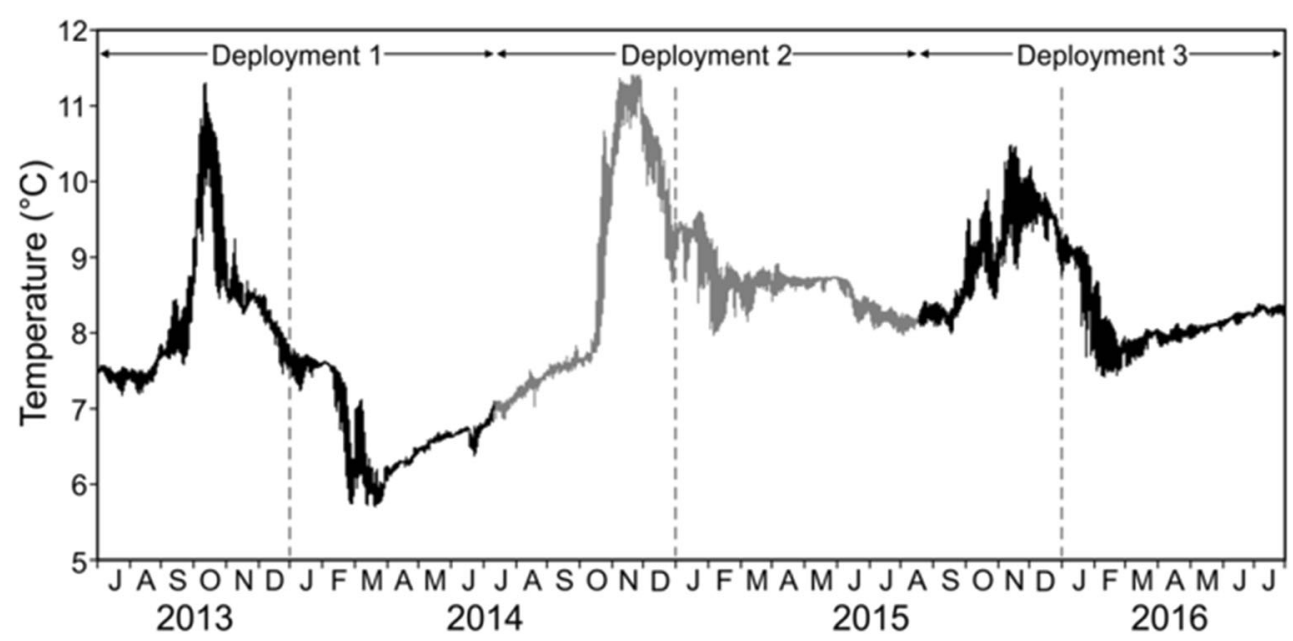

discharge pattern of the Kitimat River at the head of the fjord was clearly affected by the change in winter precipitation. In particular, the river responded quickly to the October rainfall, with a high discharge in October of 2014. The lack of snow accumulation led to a low discharge during spring melt in May of 2015 relative to the preceding year and the 50-year mean (Fig. 8). The Kitimat is not the largest river that flows into this fjord system (Wan et al. 2017), but the other principal rivers (Kildala, Kitlope, and Kemano) are also rainfed/snowfed hybrid rivers (Morrison et al. 2012), such that the Kitimat River provides a good proxy for input from rainfed/snowfed rivers. Also, the Kitimat River is likely a major source of fluvial particles into the sediment traps, because station FOC is directly in the path of its outflow.
In the first years of our record, the main freshwater flux and the peak particle flux occurred in May (Fig. 9, Table 3). During the warm year (year 2), however, most of the freshwater and most of the particles arrived in October, along with heavy rainstorms. The ratio of May:October particle flux was much lower in the second year than the first (Table 3).

With only 3 years of particle collection, we cannot say whether the Blob year was unusual in particle flux. However, we can compare the rainfall and river discharge during this period with the 50 years of data collected by Environment and Climate Change Canada. No individual day in 2014 represented a maximum in rainfall or river discharge relative to the 50-year record (Figs. 10 and 11). However, October, 2014 represented the highest monthly
Fig. 7 a Time series of chlorophyll fluorescence overlain with the cumulative sum of chlorophyll measured during the 3-year deployment. b Time series of turbidity overlain with the cumulative sum of turbidity. The turbidity sensor was not available during the third deployment, so there are only 2 years of turbidity data
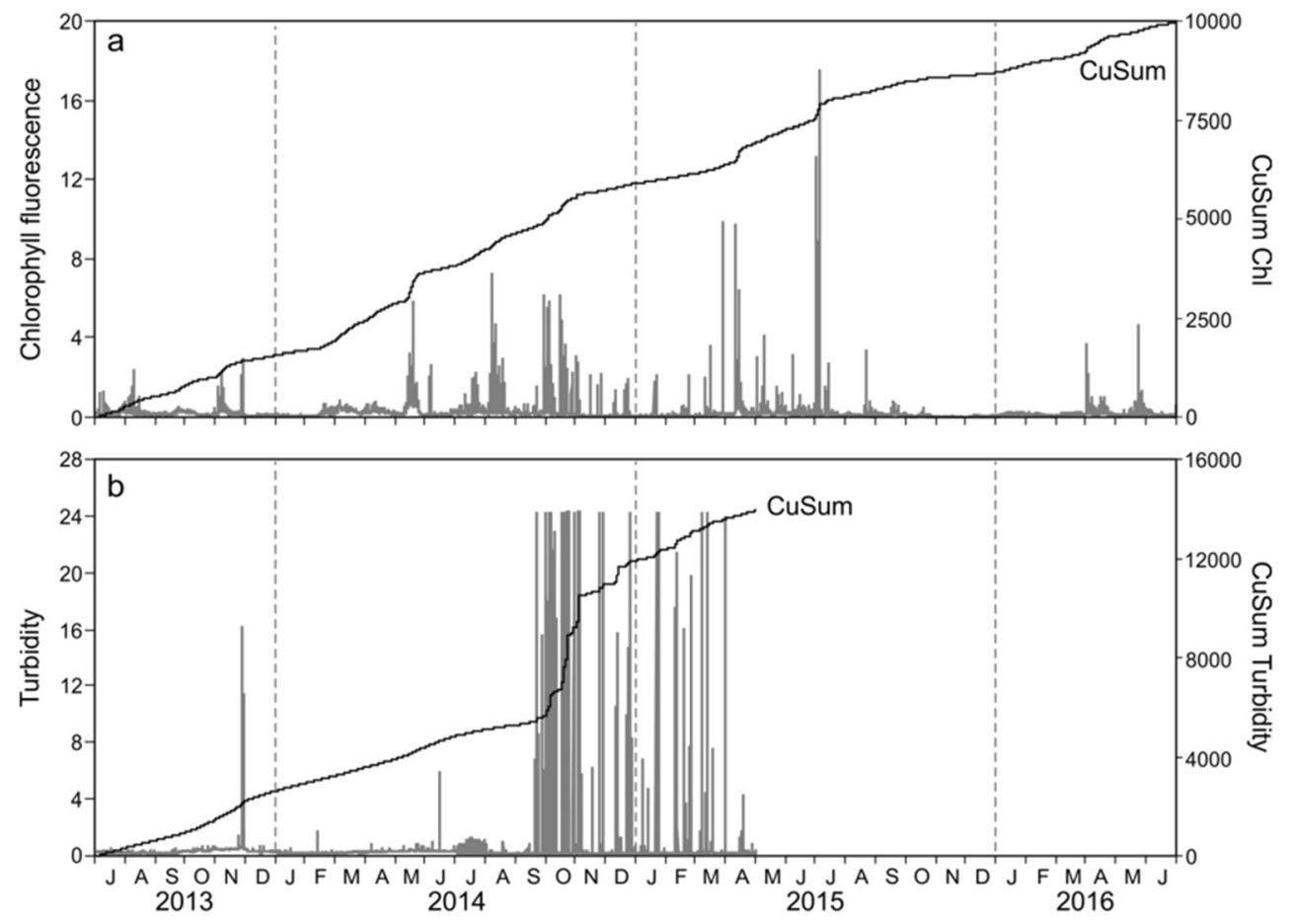
Fig. 8 Monthly rainfall (gray) and snow accumulation (white) at Kitimat, by deployment year (ac) and averaged over 1967-2016, from Environment and Climate Change Canada (http://climate. weather.gc.ca/)
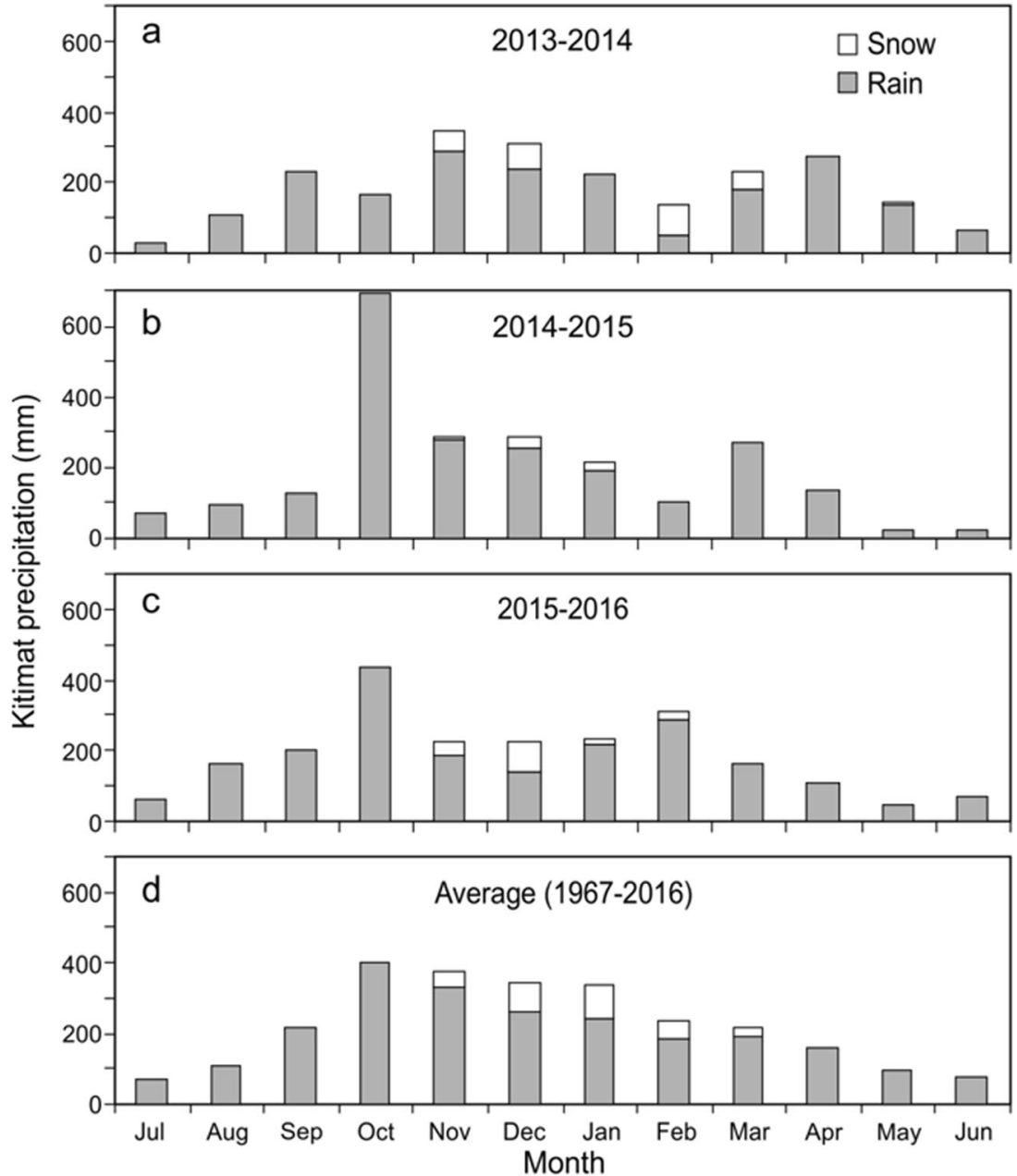

average on record, for both rainfall and river discharge (Figs. 10 and 11). The average daily rainfall in October 2014 $\left(24.8 \mathrm{~mm} \mathrm{day}^{-1}\right)$ was 2.5 standard deviations above the 50 year mean $\left(13.2 \mathrm{~mm} \mathrm{day}^{-1}\right)$, while the average river discharge in that month $\left(316 \mathrm{~m}^{3} \mathrm{~s}^{-1}\right)$ was 2.2 standard deviations above the mean $\left(179 \mathrm{~m}^{3} \mathrm{~s}^{-1}\right)$.

\section{Discussion}

The time series show strong interannual variability in particle flux and composition, as well as in water properties (e.g., Figs. 3 and 6). In particular, there was a significant difference in the timing and magnitude of particle flux and turbidity
Fig. 9 Time series of particle flux at $\mathrm{FOC1}$ overlain with rainfall and river discharge, binned to match the sediment trap collection intervals. Since the three time series have different magnitudes and different units, all three are shown as fractions of their total accumulation over the 3-year record (July 2013-June 2016)

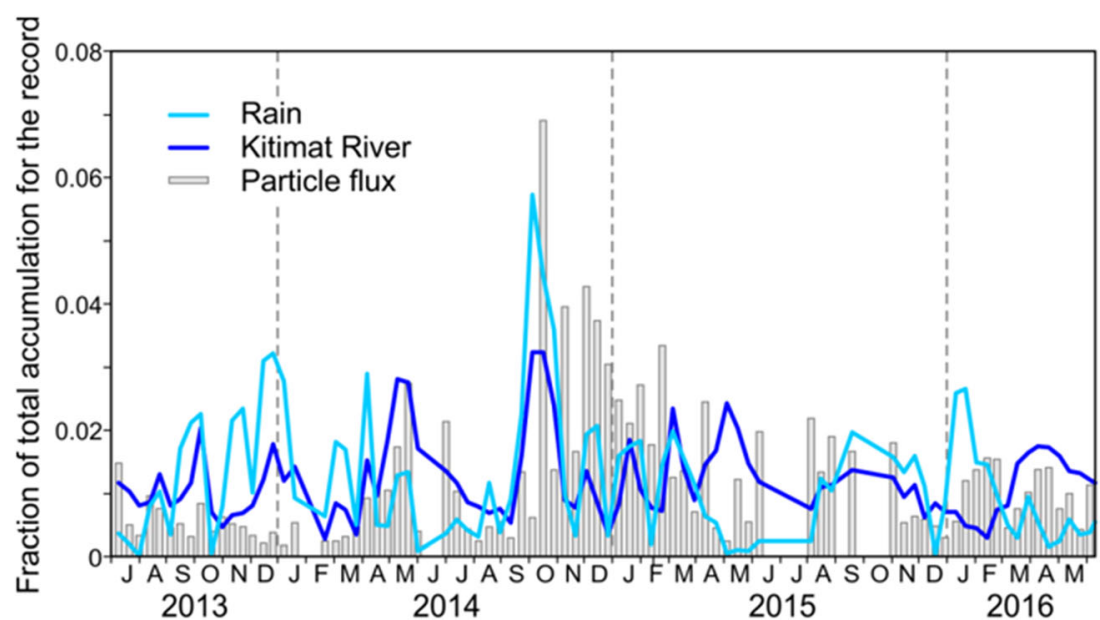


Table 3 May/October comparison for the first 2 years of sediment trap deployment at FOC1. Year 3 was not included because of the incomplete preservation of multiple samples in October 2016. Values in italics indicate a significant difference between year 1 and year $2(p<0.05)$. Precision estimates indicate one standard deviation

\begin{tabular}{lll}
\hline & Year 1 & Year 2 \\
\hline October daily rain (mm/day) & $6.4 \pm 14.2$ & $24.8 \pm 19.4$ \\
October river discharge $\left(\mathrm{m}^{3} \mathrm{~s}^{-1}\right)$ & $133 \pm 161$ & $316 \pm 211$ \\
October particle flux $\left(\mathrm{g} \mathrm{m}^{-2}\right.$ day $\left.^{-1}\right)$ & 0.24 & 1.00 \\
May rain (mm) & $4.5 \pm 9.9$ & $0.72 \pm 2.2$ \\
May river discharge $\left(\mathrm{m}^{3} \mathrm{~s}^{-1}\right)$ & $287 \pm 110$ & $218 \pm 63$ \\
May particle flux $\left(\mathrm{g} \mathrm{m}^{-2} \mathrm{day}^{-1}\right)$ & 0.65 & 0.47 \\
May/October rain ratio & 0.70 & 0.03 \\
May/October river discharge ratio & 2.2 & 0.7 \\
May/October particle flux ratio & 2.7 & 0.5 \\
\hline
\end{tabular}

between the first and second years. The contrast suggests a change in forcing between the 2 years. The patch of anomalously warm water ("the Blob") mentioned earlier likely caused this change. While the best-known effects of the Blob occurred in the open ocean (Bond et al. 2015), the 50$\mathrm{m}$ temperature record at the FOC mooring site suggests that the anomalously warm water also arrived in Douglas Channel in the autumn of 2014 (Fig. 6). This timing is consistent with the observation of mid-depth exchange between the shelf and the fjord system in September to early May (Wan et al. 2017).

The appearance of the warm water in the fjord system probably contributed to the heavy autumn rainfall in 2014, which, in turn resulted in heavy particle flux. The surface water of Douglas Channel was visibly turbid during our sampling expedition in October 2014, during the heavy rainfall, and flux out of the euphotic zone has been shown to relate strongly to surface particle concentration (Luo et al. 2014; Macdonald 1983; Pawlowicz et al. 2017). Terrigenous material enters this system predominantly in May/June during freshet and in October-November, during the heavy rains, as indicated by the low $\delta^{13} \mathrm{C}$ composition and the high $\mathrm{C} / \mathrm{N}$ ratio of the trapped particles at those times. (Terrestrial plants generally have higher $\mathrm{C} / \mathrm{N}$ ratios and lower $\delta^{13} \mathrm{C}$ than marine plants (Peters et al. 1978).) Particles associated with biological blooms in surface seawater, conversely, mainly enter the vertical flux in later summer (July-September, especially August).

While most of the blooms observed during the 3-year deployment occurred during spring and summer, a long-lasting sedimentation event consisting largely of biological material was observed in December 2014-February 2015 (hereinafter referred to as the "winter bloom"), during the second year of
Fig. 10 a Daily discharge of the Kitimat River. b Daily discharge binned to monthly average. Dashed line indicates the 19672016 average, with the full range of daily discharge shown in gray. The solid line indicates the daily discharge for 2014. October 2014 represented the highest monthly average discharge of the 50-year record

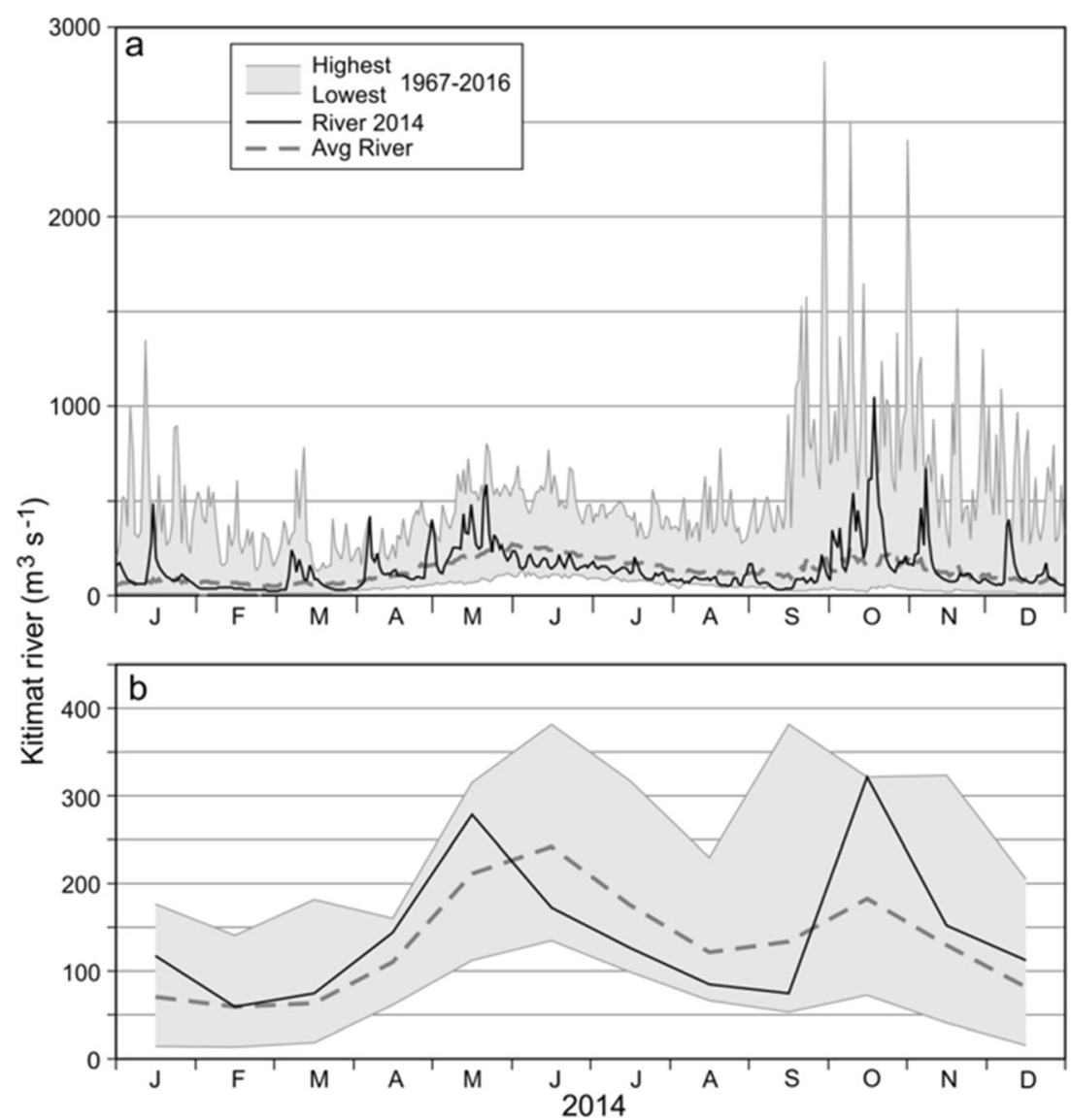


Fig. 11 a Daily rainfall at Kitimat. b Daily rainfall binned to monthly average. Dashed line indicates the 1967-2016 average, with the full range of daily discharge shown in gray. The solid line indicates the daily rainfall for 2014. October 2014 represented the highest monthly average rainfall in the 50-year record

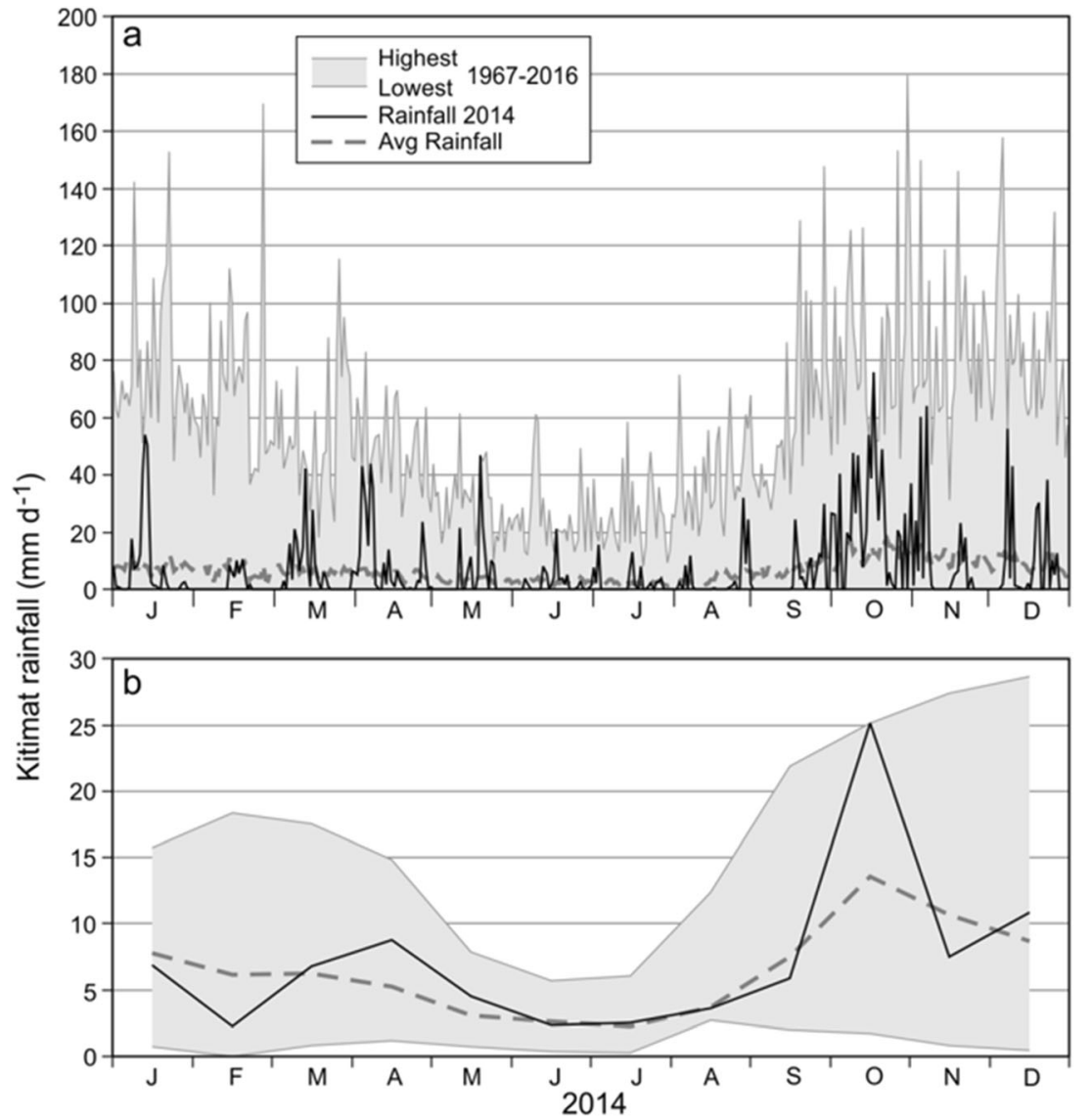

deployment. The protracted winter bloom during the Blob year was evidenced in the sediment trap record by the high flux and concentration of biogenic silica and by high $\delta^{13} \mathrm{C}$ values (Fig. 3e). It was confirmed by microscopy, which revealed a very high flux of diatom frustules during that time: the number of cells per 12-day sample was about 83 times as high in early December $2014\left(8.1 \times 10^{6}\right)$ as it had been in early November $\left(9.8 \times 10^{4}\right)$ (Fig. 5). In addition, surface chlorophyll data, derived from the MODIS Aqua ocean color sensor, show a bloom (chlorophyll a $10-20 \mathrm{mg} \mathrm{m}^{-3}$ ) that extended throughout upper Douglas Channel ( $\sim 50 \mathrm{~km}$ long; Fig. S1) in late December, 2014.

It is unlikely that the diatom frustules could have reached the FOC trap from the open ocean (Hecate Strait): the velocity of the inflowing water at $50 \mathrm{~m}$ was $0-0.1 \mathrm{~m} / \mathrm{s}$ during the trap deployment (Wan et al. 2017), and the trap was located about $125 \mathrm{~km}$ from Hecate Strait, implying a minimum transit time at that depth of 14.5 days. Marine phytoplankton have been observed to sink at rates of $0.05-30 \mathrm{~m} /$ day in laboratory conditions (Eppley et al. 1967), with larger cells sinking faster. In the ocean, large blooms of diatoms have been observed to sink at rates of 40-150 m/day (Smetacek 1985 and references therein). Since the winter bloom sedimentation event was dominated by large, chain-forming diatoms (Table S1), the cells likely sank at a rate of 10 to $100 \mathrm{~s}$ of meters a day; the sinking diatoms would likely have reached the 50-m traps in $<1-5$ days. It is likely that the trapped particles high in biogenic silica originated within the inlet.

In contrast to the clear bloom signal in biogenic $\mathrm{Si}, \delta^{13} \mathrm{C}$, and diatom frustules, however, the fluorometer moored just below the trap did not show a peak in chlorophyll a fluorescence during the winter bloom, as it did during regular spring and summer blooms (Fig. 7). Similarly, the percent organic carbon was not elevated (Fig. 3b). The apparent paradox may be explained by rapid remineralization and recycling of the soft tissue parts of the phytoplankton (organic C, N, chlorophyll), likely facilitated by zooplankton grazing near the surface, with a high export of the hard silica frustules (e.g., Ragueneau et al. 2006). A high zooplankton population during this winter bloom is indicated by a high flux of fecal pellets at this time (about three times as high in December as in November, 2014; Fig. 5).

During warm water events, such as El Niños in the Santa Barbara Basin off California, surface water has been observed to be depleted in macronutrients (Shipe et al. 2002), resulting in low surface productivity and blooms with a low proportion of diatoms. However, the Douglas Channel system is much more tightly coupled to terrestrial runoff than is the Santa Barbara Basin, and the river discharge is enriched in silicate, relative to other nutrients (Macdonald et al. 1983b). 
Fig. 12 Silicate molar flux vs. organic carbon molar flux captured by the sediment traps at FOC1 for July 2013-June 2016. Brown triangles represent background (nonbloom conditions). Open green circles represent occasions when the sinking organic matter was dominated by marinederived material (defined as $\delta^{13} \mathrm{C} \geq-22 \%$ o). Solid green circles represent the winter bloom sedimentation event that occurred in December 2014-February 2015

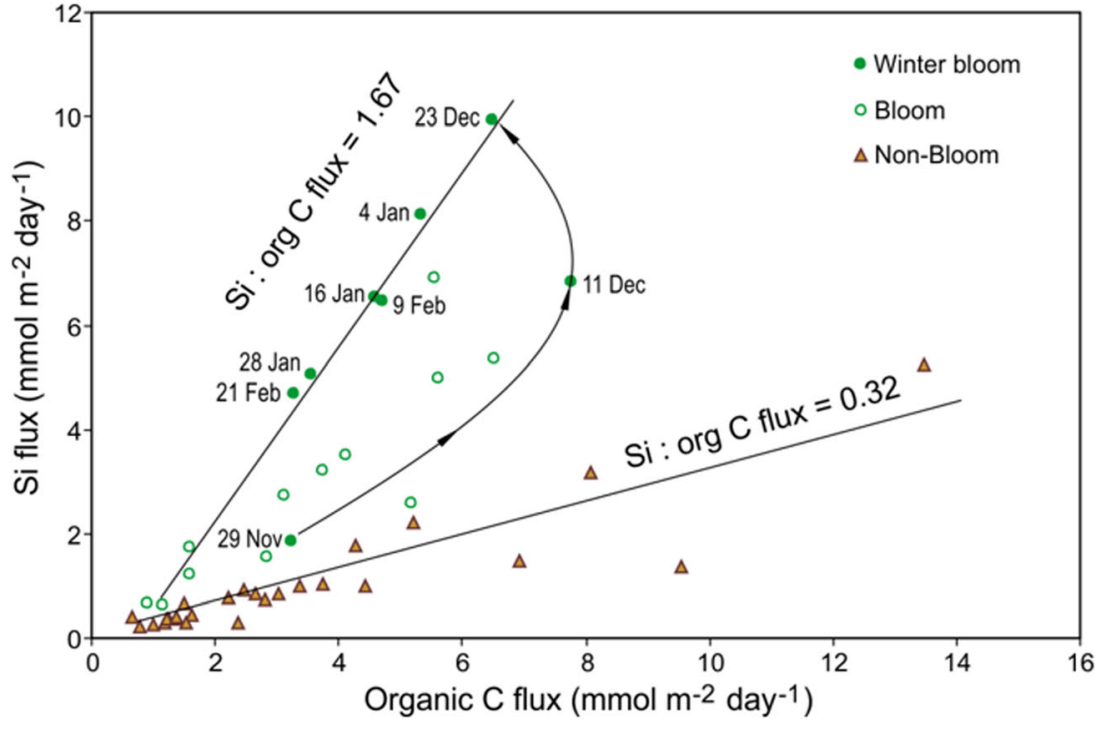

Soft tissue, which incorporates the organic C and N, would be favored for remineralization over the hard, silicate frustules (Ragueneau et al. 2006). Nutrients remineralized below the surface but still in the upper layer of the water column could have been returned to the surface by wind mixing and estuarine circulation. Winds during December 2014-February 2015 were variable $(0-15 \mathrm{~m} / \mathrm{s}$, Wan et al. 2017) and mainly down-channel. The wind-influenced layer in that area is usually 8-12 m deep (Wan et al. 2017), but wind could occasionally have mixed nutrient-enriched subsurface water from as deep as 50-70 $\mathrm{m}$ during winter storms.

There remains the question of how there could have been enough light to support such a protracted diatom bloom in the winter, given that the site is north of $53^{\circ}$ latitude and covered by cloud most of that time. We propose that the warm water of the Blob, together with higher-than-usual freshwater runoff during December-February that year, caused strong, nearsurface stratification that prevented the diatoms from being mixed below the shallow euphotic zone. In addition, Parsons et al. (1978) found that, where silicate was available in excess, low light favored diatoms over other phytoplankton. Regardless of the mechanism, the bloom did occur, as evidenced by $\delta^{13} \mathrm{C}, \%$ biogenic $\mathrm{Si}$, the microscopic analysis of trap contents, and the satellite ocean color imagery. Possibly, the warmer water also facilitated the early zooplankton bloom (e.g., Mackas et al. 2012), allowing grazers to take advantage of the phytoplankton bloom.

When the bloom began, the fluxes of organic carbon and silica increased together, from the collection interval centered on November 29th to that centered on December 11 th (Fig. 12). Then, over the subsequent 12 days, the flux of silica increased, while that of organic carbon decreased; this was likely when the phytoplankton bloom was still increasing, but the zooplankton were beginning to graze on it, recycling more of the organic carbon in the surface layer. For the remainder of the time, until the end of the bloom in late February, the fluxes of biogenic silica and organic carbon declined together, at a steady molar ratio of about 1.67.

\section{Conclusion}

Our 3-year sediment trap deployment in Douglas Channel captured three distinct "hydrological" years with three different particle flux records. The warm water "Blob" arrived at the coast during the second year of the deployment, bringing warm water, heavy autumn rainfall, and little snow. The heavy rainfall and river discharge in October 2014, the highest in 50 years $\left(69.4 \mathrm{~cm}\right.$ and $0.85 \mathrm{~km}^{3}$, respectively), resulted in turbid water and a high flux of mainly terrigenous sinking particles.

During the warm winter of 2014/2015, we observed a protracted winter diatom bloom. Longer records would be required to inform us whether or not warm years in general support winter blooms. A question that arises from this work is how inshore, winter blooms might affect the long-term export of silicate to the shelf and the availability of food for juvenile and adult fish. Given the importance of diatoms to food webs that support salmon productivity (e.g., Parsons and Whitney 2012), these winter blooms clearly bear future investigation.

Inshore waters respond differently to climate events than do coastal waters and the open ocean, because such events are mediated by the strong influence of land and the terrestrial hydrological system. With long-term climate records and models projecting continued warming and freshening of coastal waters and increased precipitation for coastal British Columbia (e.g., Cummins and Masson 2014; Parsons and Whitney 2012), years like the Blob year will likely become more common. 
The value of the dataset presented here is that it provides a temporal record of particle flux throughout the year for Douglas Channel/Kitimat Fjord. We anticipated the importance that river inflow would play, but the importance of rainfall was unexpected, and the diatom flux in mid-winter was a complete surprise. Given the importance of diatoms to marine food webs (e.g., Parsons and Whitney 2012), this finding is of the first order in terms of the ecology of this system.

Acknowledgements We thank David Spear for designing and deploying the mooring and Lucius Perreault, Ron Lindsay, Mike Dempsey, Kenny Scozzafava, Hugh Maclean, Scott Rose, Roger Savoie, and Di Wan for technical support at sea. We appreciate the professional and friendly assistance of the officers and crew of the CCGS John P. Tully. Patricia Kimber prepared the figures, and Charles Hannah provided helpful discussions of the physical oceanography of the fjord system. Two anonymous reviewers offered insightful comments on an earlier draft of this manuscript. The MODIS Aqua data were provided free of charge by the NASA, and the precipitation and river discharge data were provided free of charge by Environment and Climate Change Canada.

Funding Information This work was funded by Fisheries and Oceans Canada and by the Government of Canada's World Class Prevention, Preparedness and Response for Oil Spills from Ships Initiative.

Open Access This article is distributed under the terms of the Creative Commons Attribution 4.0 International License (http:// creativecommons.org/licenses/by/4.0/), which permits unrestricted use, distribution, and reproduction in any medium, provided you give appropriate credit to the original author(s) and the source, provide a link to the Creative Commons license, and indicate if changes were made.

\section{References}

Baker, E.T. 1984. Patterns of suspended particle distribution and transport in a large fjord-like estuary. Journal of Geophysical Research 89 (C4): 6553-6566.

Baker, E.T., and H.B. Milburn. 1983. An instrument system for the investigation of particle fluxes. Continental Shelf Research 1 (4): 425 435.

Bond, N.A., M.F. Cronin, H. Freeland, and N. Mantua. 2015. Causes and impacts of the 2014 warm anomaly in the NE Pacific. Geophysical Research Letters 42 (9): 3414-3420.

Calvert, S.E., and T.F. Pedersen. 1995. On the organic carbon maximum on the continental slope of the eastern Arabian Sea. Journal of Marine Research 53 (2): 269-296.

Calvert, S.E., T.F. Pedersen, and R.E. Karlin. 2001. Geochemical and isotopic evidence for post-glacial palaeoceanographic changes in Saanich Inlet, British Columbia. Marine Geology 174 (1-4): 287-305.

Cui, X., T.S. Bianchi, C. Savage, and R.W. Smith. 2016. Organic carbon burial in fjords: Terrestrial versus marine inputs. Earth and Planetary Science Letters 451: 41-50.

Cummins, P.F., and D. Masson. 2014. Climatic variability and trends in the surface waters of coastal British Columbia. Progress in Oceanography 120: 279-290.

Dagg, M. 1993. Sinking particles as a possible source of nutrition for the large calanoid copepod Neocalanus cristatus in the subarctic Pacific Ocean. Deep-Sea Research Part I 40 (7): 1431-1445.

Eppley, R.W., R.W. Holmes, and J.D.H. Strickland. 1967. Sinking rates of marine phytoplankton measured with a fluorometer. Journal of Experimental Marine Biology and Ecology 1 (2): 191-208.
Fischer, G., and G. Karakas. 2009. Sinking rates and ballast composition of particles in the Atlantic Ocean: Implications for the organic carbon fluxes to the deep ocean. Biogeosciences 6 (1): 85-102.

Gardner, W.D., I.D. Walsh, and M.J. Richardson. 1993. Biophysical forcing of particle production and distribution during a spring bloom in the North Atlantic. Deep-Sea Research Part II 40 (1-2): 171-195.

Gardner, W.D., P.E. Biscaye, and M.J. Richardson. 1997. A sediment trap experiment in the Vema Channel to evaluate the effect of horizontal particle fluxes on measured vertical fluxes. Journal of Marine Research 55 (5): 995-1028.

Hobson, L.A. 2009. Phytoplankton ecology of the northeast Pacific Ocean: An illustrated guide. LCJLMES Press, Victoria, B.C., Canada. ix $+33 p p+83$ plates.

Hood, E., J. Fellman, R.G.M. Spencer, P.J. Hernes, R. Edwards, D. D'Amore, and D. Scott. 2009. Glaciers as a source of ancient and labile organic matter to the marine environment. Nature 462 (7276): 1044-1047.

Johannessen, S.C., M.C. O'Brien, K.L. Denman, and R.W. Macdonald. 2005. Seasonal and spatial variations in the source and transport of sinking particles in the Strait of Georgia, British Columbia, Canada. Marine Geology 216 (1-2): 59-77.

Johannessen, S.C., R.W. Macdonald, C.A. Wright, and D.J. Spear. 2017. Short-term variability in particle flux: Storms, blooms and river discharge in a coastal sea. Continental Shelf Research 143: 29-42.

Kniskern, T.A., J.A. Warrick, K.L. Farnsworth, R.A. Wheatcroft, and M.A. Goñi. 2011. Coherence of river and ocean conditions along the US West Coast during storms. Continental Shelf Research 31 (78): 789-805.

Luo, Y., L.A. Miller, B. De Baere, M. Soon, and R. Francois. 2014. POC fluxes measured by sediment traps and ${ }^{234} \mathrm{Th}:{ }^{238} \mathrm{U}$ disequilibrium in Saanich Inlet, British Columbia. Marine Chemistry 162: 19-29.

Macdonald, R.W. 1983. The distribution and dynamics of suspended particles in the Kitimat fjord system. In Proceedings of a workshop on the Kitimat marine environment, ed. R.W. Macdonald, 116-137. Sidney: Ministry of Supply and Services Canada.

Macdonald RW, Bornhold BD, Webster I (1983a) The Kitimat fjord system: an introduction. In Proceedings of a workshop on the Kitimat marine environment, ed. R.W. Macdonald, 2-13. Sidney: Ministry of Supply and Services Canada.

Macdonald, R.W., W.J. Cretney, C.S. Wong, and P. Erickson. 1983b. Chemical characteristics of water in the Kitimat fjord system. In Proceedings of a workshop on the Kitimat marine environment, ed. R.W. Macdonald, 66-87. Sidney: Fisheries and Oceans Canada.

Mackas, D.L., W. Greve, M. Edwards, S. Chiba, K. Tadokoro, D. Eloire, M.G. Mazzocchi, S. Batten, A.J. Richardson, C. Johnson, E. Head, A. Conversi, and T. Peluso. 2012. Changing zooplankton seasonality in a changing ocean: Comparing time series of zooplankton phenology. Progress in Oceanography 97-100: 31-62.

Morrison, J., M.C. Quick, and M.G.G. Foreman. 2002. Climate change in the Fraser River watershed: Flow and temperature projections. Journal of Hydrology 263 (1-4): 230-244.

Morrison, J., M.G.G. Foreman, and D. Masson. 2012. A method for estimating monthly freshwater discharge affecting British Columbia coastal waters. Atmosphere-Ocean 50: 1-8. https://doi. org/10.1080/07055900.2011.637667.

Mortlock, R.A., and P.N. Froelich. 1989. A simple method for the rapid determination of biogenic opal in pelagic marine sediments. DeepSea Research 36 (9): 1415-1426.

O’Brien, M.C., M. Soon, B. Nielsen, C. Elliot, T. Juhasz, R.W. Macdonald, K.L. Denman, R.E. Thomson, and S.E. Calvert. 2000. Sediment trap data from the Strait of Georgia, May, 1995, to January, 1999, 92. Sidney: Fisheries and Oceans Canada.

Olsen, C.R., N.H. Cutshall, and I.L. Larsen. 1982. Pollutant-Particle associations and dynamics in coastal marine environments: A review. Marine Chemistry 11 (6): 501-533. 
Parsons, T.R., and F.A. Whitney. 2012. Did volcanic ash from Mt. Kasatoshi in 2008 contribute to a phenomenal increase in Fraser River sockeye salmon (Oncorhynchus nerka) in 2010? Fisheries Oceanography 21: 374-377.

Parsons, T.R., P.J. Harrison, and R. Waters. 1978. An experimental simulation of changes in diatom and flagellate blooms. Journal of Experimental Marine Biology and Ecology 32 (3): 285-294.

Pawlowicz, R., R. Di Costanzo, M. Halverson, E. Devred, and S.C. Johannessen. 2017. Advection, surface area, and sediment load of the Fraser River plume under variable wind and river forcing. Atmosphere-Ocean 55 (4-5): 293-313.

Peña, M.A., K.L. Denman, J.R. Forbes, S.E. Calvert, and R.E. Thomson. 1996. Sinking particle fluxes from the euphotic zone over the continental slope of an eastern boundary current region. Journal of Marine Research 54 (6): 1097-1122.

Peña, M.A., K.L. Denman, S.E. Calvert, R.E. Thomson, and J.R. Forbes. 1999. The seasonal cycle in sinking particle fluxes off Vancouver Island, British Columbia. Deep-Sea Research Part II 46 (11-12): 2969-2992.

Peters, K.E., R.E. Sweeney, and I.R. Kaplan. 1978. Correlation of carbon and nitrogen stable isotope ratios in sedimentary organic matter. Limnology and Oceanography 23 (4): 598-604.

Ragueneau, O., S. Schultes, K. Bidle, P. Claquin, and B. Moriceau. 2006. $\mathrm{Si}$ and $\mathrm{C}$ interactions in the world ocean: Importance of ecological processes and implications for the role of diatoms in the biological pump. Global Biogeochemical Cycles 20 (4): GB4S02. https://doi. org/10.1029/2006GB002688.

Shaw, J., C.D. Stacey, Y. Wu, and D.G. Lintern. 2017. Anatomy of the Kitimat fjord system. Geomorphology 293: 108-129.

Shipe, R.F., U. Passow, M.A. Brzezinski, W.M. Graham, D.K. Pak, D.A. Siegel, and A.L. Alldredge. 2002. Effects of the 1997-98 El Niño on seasonal variations in suspended and sinking particles in the Santa Barbara basin. Progress in Oceanography 54 (1-4): 105-127.

Smetacek, V.S. 1985. Role of sinking in diatom life-history cycles: Ecological, evolutionary and geological significance. Marine Biology 84 (3): 239-251.

Stocker, T.F., D. Qin, G.-K. Plattner, L.V. Alexander, S.K. Allen, N.L. Bindoff, F.-M. Bréon, J.A. Church, U. Cubasch, S. Emori, P. Forster, P. Friedlingstein, N. Gillett, J.M. Gregory, D.L. Hartmann, E. Jansen, B. Kirtman, R. Knutti, K. Krishna Kumar, P. Lemke, J.
Marotzke, V. Masson-Delmotte, G.A. Meehl, I.I. Mokhov, S. Piao, V. Ramaswamy, D. Randall, M. Rhein, M. Rojas, C. Sabine, D. Shindell, L.D. Talley, D.G. Vaughan, and S.-P. Xie. 2013. Technical summary. In Climate change 2013: The physical science basis. Contribution of working group I to the fifth assessment report of the Intergovernmental Panel on Climate Change, ed. T.F. Stocker, D. Qin, G.-K. Plattner, M. Tignor, S.K. Allen, J. Boschung, A. Nauels, Y. Xia, V. Bex, and P.M. Midgley. Cambridge: Cambridge University Press.

Thunell, R.C. 1998. Particle fluxes in a coastal upwelling zone: Sediment trap results from Santa Barbara Basin. Deep-Sea Research Part II 45 (8-9): 1863-1884.

Timothy, D.A., M.Y.S. Soon, and S.E. Calvert. 2003. Settling fluxes in Saanich and Jervis inlets, British Columbia, Canada: Sources and seasonal patterns. Progress in Oceanography 59 (1): 31-73.

Wan, D., C. Hannah, M.G.G. Foreman, and S. Dosso. 2017. Subtidal circulation in a deep-silled fjord: Douglas Channel, British Columbia. Journal of Geophysical Research Oceans 122 (5): 4163-4182.

Wright, C.A., S. Vagle, C. Hannah, and S.C. Johannessen. 2015. Physical, chemical and biological oceanographic data collected in Douglas Channel and the approaches to Kitimat, July 2013 June 2014. In Canadian data report of hydrography and ocean sciences, 196: viii+66. Sidney: Fisheries and Oceans Canada.

Wright, C.A., S. Vagle, C. Hannah, S.C. Johannessen, D.J. Spear, and D. Wan. 2016. Physical, chemical and biological oceanographic data collected in Douglas Channel and the approaches to Kitimat, October 2014 - July 2015. In Canadian data report of hydrography and ocean sciences, 200:viii $+74 p p$. Sidney: Fisheries and Oceans Canada.

Wright, C.A., S. Vagle, C. Hannah, S.C. Johannessen, D.J. Spear, and D. Wan 2017. Physical, chemical and biological oceanographic data collected in Douglas Channel and the approaches to Kitimat, October 2015-July 2016. In Canadian data report of hydrography and ocean sciences, 202: $x+139 p p$. Sidney: Fisheries and Oceans Canada.

Zúñiga, D., N. Villacieros-Robineau, E. Salgueiro, F. Alonso-Pérez, G. Rosón, F. Abrantes, and C.G. Castro. 2016. Particle fluxes in the NW Iberian coastal upwelling system: Hydrodynamical and biological control. Continental Shelf Research 123: 89-98. 